\title{
Synthesis, Characterization and Dry Sliding Wear Behavior of In-situ Formed TiAl Precipitate Reinforced A356 Alloy Produced by Mechanical Alloying Method
}

\author{
Özyürek Dursun ${ }^{a *}$,Tuncay Tansel ${ }^{a}$, Evlen Hatice $^{a}$, Çiftci İbrahim ${ }^{a}$ \\ ${ }^{a}$ Karabuk University, Technology Faculty, 78100, Karabuk, Turkey
}

Received: June 9, 2015; Revised: July 21, 2015

\begin{abstract}
In this present study, the effect of in-situ formed $\mathrm{TiAl}_{3}$ and AlTiSi intermetallic phases within $\mathrm{A} 356$ aluminum alloy on the dry sliding wear behaviors was investigated. The $\mathrm{TiAl}_{3}$ and AlTiSi intermetallic phases were obtained by synthesizing A356 aluminum alloy containing 6\% titanium for different times $(1,4,8$ and $16 \mathrm{~h})$. The cold pressed samples were sintered in an argon atmosphere at $530{ }^{\circ} \mathrm{C}$ for one hour $\left(10^{\circ} \mathrm{C} / \mathrm{min}\right.$.) and then cooled in the furnace. The sintered samples were synthesized at $550{ }^{\circ} \mathrm{C}$ for different times $(1,4,8$ and $16 \mathrm{~h})$, and the in-situ aluminum matrix composites (AMCs) were produced. Wear tests of the AMCs were performed under $30 \mathrm{~N}$ load and at $1 \mathrm{~ms}^{-1}$ sliding speed for five different sliding distances. As the result of the studies performed, formation of in-situ $\mathrm{TiAl}_{3}$ and AlTiSi intermetallic phases were detected. With the increase in synthesizing time, the porosity in the structure was found to be reduced. In addition, it was observed that the densities and hardness of the composites increased depending on the synthesizing time. The wear test results revealed that increasing hardness values of A356 +6\% Ti AMCs decreased the weight loss.
\end{abstract}

Keywords: aluminum composites, synthesis, wear behavior, mechanical alloying

\section{Introduction}

Aluminum matrix composites are produced (AMCs) with the addition of hard reinforcement phases such as oxides, carbides and borides into the alloy powders through powder metallurgy method. In traditional powder metallurgy, hard additional phases are added into the alloy externally in composite production ${ }^{1-7}$. This production method is called as ex-situ. The major advantage of the composites called as ex-situ is their stability at high temperature applications. These composite materials provide the performance expected from them without decomposing additional phases in the structure at high temperature applications ${ }^{8-10}$. However, the most important disadvantages of these composites are the weak interfaces formed between matrix and reinforcement phase and the non-homogenous distribution of the reinforcement phase $^{11}$. In these ex-situ composites, wear damage occurs during their service life by friction due to the weak bonding between matrix and reinforcement phase. For the elimination of this problem in AMCs, the hard phases, which increase the strength of composite, in the structure are formed through various heat treatment methods (such as aging and synthesizing) $)^{12-16}$. The usage of AMCs in engineering applications increases day by day. For this reason, in order to increase AMCs' wear resistance, the studies carried out in the composites produced in-situ have been increasing ${ }^{17-22}$. In order to improve the tribological properties of aluminum alloys, titanium aluminates are formed within the matrix through the addition of Ti to these alloys. These aluminates are hard and coherent with the matrix. Hence, wear resistance of Al alloys can be improved. Al-Ti alloys are considered to be one of the most important material groups in the future.

*e-mail: dozyurek@karabuk.edu.tr
In cast $\mathrm{Al}-\mathrm{Si}$ alloys, $\mathrm{Ti}$ is an important alloying element due to its grain refining effect. The solubility limits of titanium in $\alpha$-Al are in between 0.12 to $0.15 \%{ }^{23}$. In a study carried out by Ghomashi ${ }^{24}$, the formation of AlTiSi intermetallics of various shapes and sizes in the structure of A356 (Al-Si) alloy with the addition of Ti was reported. The AlTiSi intermetallics are found in the structure as fine needles and spherical particles. It was reported in another study carried out by Zeren ${ }^{24}$ that the morphology TiAlSi intermetallics formed in the structure of Al-Si alloy is very similar to that of $\mathrm{TiAl}_{3}$ intermetallics in-situ formed in the structure of the same alloy. These alloys are preferred in space and automotive industries and in engineering applications since their oxidation and wear resistance and high temperature strengths are also high and their densities are low. Besides this, the basic problem of these alloys is their low ductility at room temperature. For the elimination of this problem, some processes such as grain refinement and heat treatment are applied ${ }^{25-27}$. So, the atomic packing and lattice structure are changed and the number of shear systems can be increased ${ }^{28}$.

In the production of $\mathrm{Al}_{-} \mathrm{TiAl}_{3}$ reinforced composite materials, various casting techniques could be used like compo casting, squeeze casting, stir casting, etc ${ }^{29}$. With ingot metallurgy, the main problem is the higher melting temperature of titanium $\left(1668{ }^{\circ} \mathrm{C}\right)$ in the preparation of Al-Titanium aluminate particulate composites. Since the melting temperature of titanium is too high as compared to aluminum, it remains in $\mathrm{Al}$ without melting (locally). This situation reduces the possibility of the production of alloys with homogeneous structure. However, in-situ $\mathrm{Al}_{-} \mathrm{TiAl}_{3}$ composite materials can be easily produced with mechanical alloying method (MA). 
With MA technique, production of composite materials for aerospace and automotive industries and also for the production of structural materials used in high temperature applications are performed ${ }^{30-38}$. Aluminum alloy components produced with powder metallurgy and containing $\mathrm{Ti}$ are preferred not only for high strength but also for the fact that titanium alloys formed in the structure increase dry sliding wear behavior of the matrix. For this reason, the aim of this study is to identify the effects of AlTiSi and $\mathrm{TiAl}_{3}$ phases on the microstructure and dry sliding wear behavior in A356-Ti in-situ composites produced with MA method depending on synthesizing time.

\section{Experimental Procedures}

\subsection{The production and characterization of composite powders}

In this present study, A356 (Al-Si-Mg) alloy powders of $<50 \mu \mathrm{m}$ were gas atomized from ingots of A356 alloy. The chemical composition of A356 ingots is given in Table 1. Elemental titanium powders used as reinforcement element are at the purity of $99.7 \%$ and have the mean powder sizes of $10 \mu \mathrm{m} .6 \%$ (wt) titanium powders were added to A356 alloy $002 \mathrm{E}$

The mixture of powders was mechanically alloyed at the ball-powder ratio of 10:1 in a SPEX Sample Preb device for 45 minutes. The mechanically alloyed powders were subjected to cold pressing at $600 \mathrm{MPa}$ (in the diameter of $10 \mathrm{~mm}$ and height of $6 \mathrm{~mm}$ ). The cold pressed powders were sintered in an argon atmosphere at the heating speed of $10{ }^{\circ} \mathrm{C} / \mathrm{min}$ at the temperature of $530{ }^{\circ} \mathrm{C}$ for one hour, and then it was cooled to room temperature in the furnace. After the sintering process, the sintered samples were again heated to $550{ }^{\circ} \mathrm{C}$ at the heating speed of $10{ }^{\circ} \mathrm{C} / \mathrm{min}$ in an argon atmosphere in the furnace and then held at this temperature for $1 \mathrm{~h}, 4 \mathrm{~h}, 8 \mathrm{~h}$ and $16 \mathrm{~h}$ in order to synthesize AMC composite. Subsequently, they were cooled to room temperature in the furnace. The synthesized AMC samples were prepared for the standard metallographic processes for microstructural examinations. The prepared samples were etched with $2 \mathrm{ml}(\mathrm{HF}), 90 \mathrm{ml}$ pure water, $5 \mathrm{ml}\left(\mathrm{HNO}_{3}\right)$ and $3 \mathrm{ml}(\mathrm{HCl})$ solution for $30-45 \mathrm{sec}$. The etched samples were characterized with X-ray diffraction (XRD/Inel Eqinox 100), scanning electron microscopy (SEM+EDS/ FEI Quanta 250), permeable electron microscopy (TEM/ FEI Tecnai G2 F30 $(200 \mathrm{kV}))$, density measurements (Archiments') and hardness measurements (Affri System VRSD-251/HV2). XRD studies were performed using an INEL XRD unit, SEM and EDS examinations were performed using an FEI Quanta 250 $(30 \mathrm{kV})$ unit. An FEI Tecnai G2 F30 (200 kV) unit was used for TEM examinations. Hardness values were calculated by taking the average of five measurements.

Dry sliding wear tests were performed on a standard pin-on-disk type wear device. The wear tests were performed according to ASTM-G99-05 standards. An AISI 4423 steel disc of 64 HRc was used as the counter surface for wear test of the AMCs produced in the diameter of $10 \mathrm{~mm}$ and in the height of $6 \mathrm{~mm}$. Before the wear tests, the surfaces of the samples were ground using 1200 grade $\mathrm{SiC}$ sandpaper in order to provide full contact with the with steel disc surface. The wear tests were carried out for five different sliding distances (400-2000 m) at a sliding speed of $1 \mathrm{~ms}^{-1}$ and under $30 \mathrm{~N}$ load. The wear samples were weighed in a digital balance with a sensitivity of $\pm 0.0001 \mathrm{~g}$ before and after each test and the weight losses were determined. After the wear tests, the worn surfaces of AMCs were examined with SEM in order to determine the wear damage and structural changes in the worn surfaces. Equation 1 is used for the calculation of the wear rates.

$$
\mathrm{Wa}=\frac{\Delta G}{d \cdot P \cdot S}
$$

where $\mathrm{Wa}$ is the wear rate $\left(\mathrm{mm}^{3} / \mathrm{Nm}\right) ; \Delta \mathrm{G}$ is the weight loss (mg); $\mathrm{P}$ is the load $(\mathrm{N})$; $\mathrm{S}$ is the sliding distance $(\mathrm{m})$ and $\mathrm{d}$ is the density $\left(\mathrm{g} / \mathrm{cm}^{3}\right)$.

\section{Results and Discussion}

After the synthesizing of A356-6\% Ti composites, $\mathrm{TiAl}_{3}$ and AlTiSi intermetallic compounds were formed in-situ in the structure depending on the synthesizing time. In Figure 1, SEM images of A356-6\% Ti composites synthesized at $550{ }^{\circ} \mathrm{C}$ for $1,4,8$ and $16 \mathrm{~h}$ are given.

The formation of pores in microstructures of the samples produced with powder metallurgy method is inevitable. In the SEM images given in Figure 1a, d, it is seen that there are some pores in the regions close to the coarse Ti particles present in the structure. In parallel with the increase in the synthesizing time, the increase in the pore dimensions can be clearly seen. These coarse pores result from Kirkendall's effect known as increasing in pore concentration ${ }^{15}$. Besides, these pores are seen to be close to the regions where more than one pore boundaries are mostly crossed. Sizes of $\mathrm{TiAl}_{3}$ phases for the 1 and $16 \mathrm{~h}$ (the shortest and longest times) synthesized specimens were determined. For the other two samples (Figure 1b, c), no measurements were made. The sizes of $\mathrm{TiAl}_{3}$ phase formed in the microstructure of A356+6\% Ti AMCs for one hour was detected to be in the range of approximately 22-32 $\mathrm{nm}$. Especially in the samples synthesized for 8 hours, in-situ $\mathrm{TiAl}_{3}$ phase can be seen much more clearly. Besides this, $\mathrm{TiAl}_{3}$ phase in the range of 45-62 $\mathrm{nm}$ were formed in the A356+6\% Ti AMCs microstructure that was synthesized for $16 \mathrm{~h}$. These results show that the dimension of $\mathrm{TiAl}_{3}$ phase formed in the structure increases depending on the increasing synthesizing time. The formation of $\mathrm{TiAl}_{3}$ phase in the structure through synthesizing can be explained with $\alpha-\mathrm{Al}$ and $\mathrm{TiAl}_{3}$ crystal structure transformations in Al-Ti diagram. A peritectic

Table 1. The chemical composition of A356 alloy used in experimental studies.

\begin{tabular}{cccccccccc}
\hline Element & $\mathbf{S i}$ & $\mathbf{M g}$ & $\mathbf{F e}$ & $\mathbf{C u}$ & $\mathbf{M n}$ & $\mathbf{Z n}$ & $\mathbf{T i}$ & $\mathbf{P b}$ & Al \\
\hline (wt \%) & 6.5 & 0.4 & 0.15 & 0.03 & 0.03 & 0.05 & 0.2 & 0.03 & Balance \\
\hline
\end{tabular}



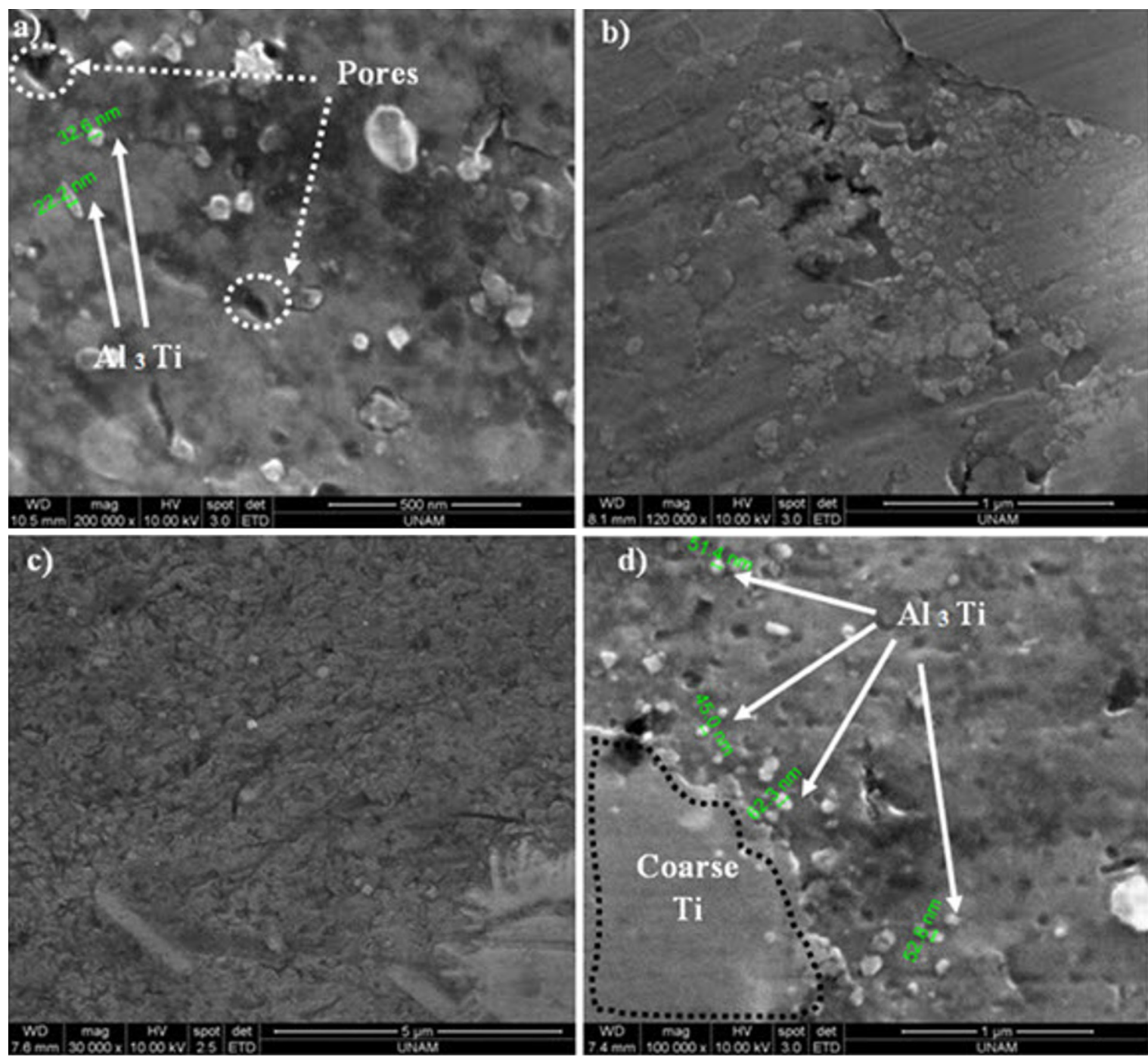

Figure 1. SEM images of A356+6\% Ti AMCs synthesized at $550{ }^{\circ} \mathrm{C}$ for 1 (a), 4 (b), 8 (c) and $16 \mathrm{~h}$ (d).

reaction can be seen from Al-Ti phase diagram between $\mathrm{TiAl}_{3}$ phase and aluminum. In-situ $\mathrm{TiAl}_{3}$ intermetallic phase formed in the structure of AMCs is located at the center of $\alpha-\mathrm{Al}$ particles. This situation was reported in a study previously made by Wang et al. ${ }^{39}$. Titanium diffuses into the boundaries of $\mathrm{Al} / \mathrm{TiAl}_{3}$ and the strong mechanical bond as the result of titanium diffusion to these regions increases the strength of the materials. The results of SEM, TEM bright region image of A356+6\% Ti AMCs synthesized for $16 \mathrm{~h}$ and EDS analyses are given in Figure 2.

In Figure 2, $\mathrm{TiAl}_{3}$ and AlTiSi intermetallic phases formed during synthesizing around the particle boundaries can be seen. In addition, when the titanium amounts present in TiAl3 and AlTiSi intermetallic phases from EDS analysis are compared, Ti amount (wt \%) in AlTiSi intermetallic phase is seen to be high. The pores formed around the particle boundaries of the material can also be seen from the SEM image. Particle boundaries are the metallurgically suitable regions for defects such as oxides, nitrides and impurities and for the nucleation and growth of possible secondary phases. In the previous studies, with the addition of titanium to Al-Si and Al-Si-Mg alloys through casting method, it is reported that AlTiSi intermetallic phase was formed in the structure in addition to $\mathrm{TiAl}_{3}$ intermetallic phase $\mathrm{e}^{23,24,40}$. In Figure 3, XRD analysis results are given. From this figure, the phases formed in the structure of A356+6\% Ti AMCs can be identified.

As it is understood from XRD analyses results, AlTiSi and $\mathrm{TiAl}_{3}$ intermetallic phases are formed in the structure depending on the synthesizing time. From the XRD analysis, $\mathrm{TiAl}_{3}$ is seen to be formed at the angles of 29, 41, $47(2 \theta)$ and AlTiSi at the angles of 29 and $47(2 \theta)$. In a study conducted by Gao et al. ${ }^{23}, \mathrm{Al}(\mathrm{TiSi})$ intermetallic phase is reported to be transformed into $\mathrm{Ti}_{7} \mathrm{Al}_{5} \mathrm{Si}_{12}$ phase depending on the increasing silicon in the alloy. In XRD results given in Figure 3, by adding Ti to A356 alloy powders, $\mathrm{TiAl}_{3}$ phase was successfully synthesized through in-situ reactions in the structure. Chianeh et al. ${ }^{15}$ stated that $\mathrm{TiAl}_{3}$ intermetallic phase is obtained at the temperature range of $500-600{ }^{\circ} \mathrm{C}$. In-situ reaction occurs during synthesizing processes as; 


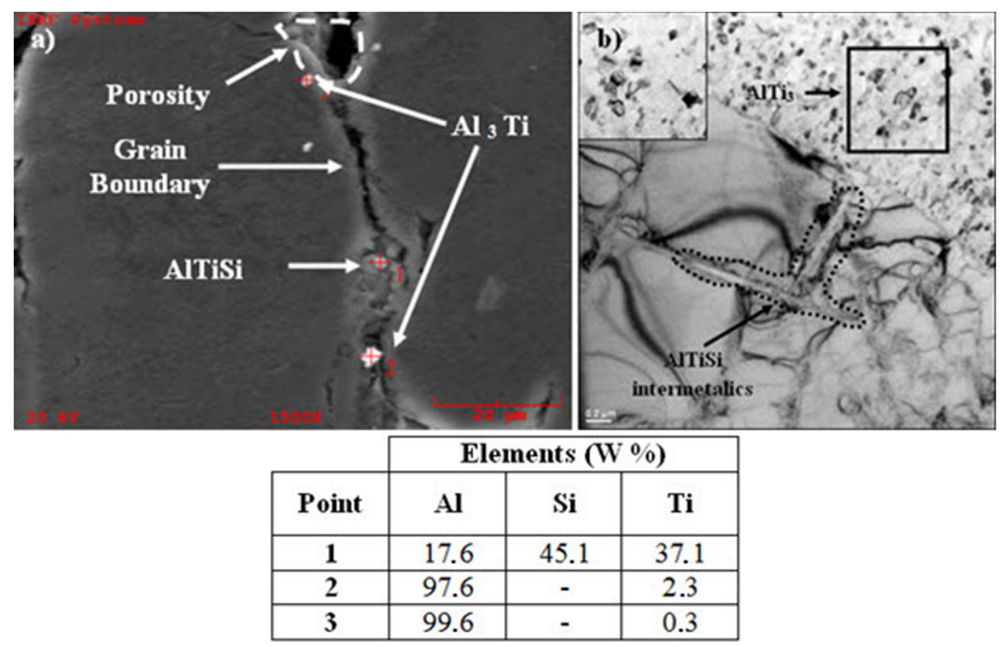

Figure 2. The image of SEM (a), EDS analysis and TEM bright area image (b) of A356+6\% Ti AMCs synthesized at the temperature of $550{ }^{\circ} \mathrm{C}$ for $16 \mathrm{~h}$.

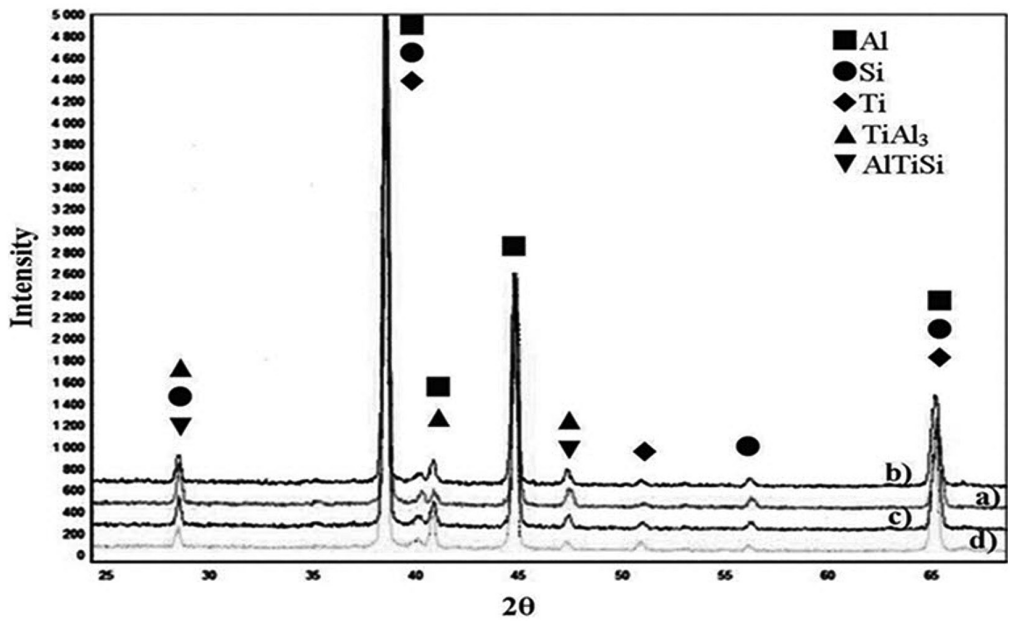

Figure 3. XRD analysis of A356+6\% Ti AMCs synthesized at the temperature of $550{ }^{\circ} \mathrm{C}$ for 1 (a), 4 (b), 8 (c) and $16 \mathrm{~h}(\mathrm{~d})$.

$\mathrm{Ti}+3 \mathrm{Al}=\mathrm{TiAl}_{3}$

In Figure 4, the density and hardness changes of A356+6\% Ti AMCs depending on the synthesizing time are given.

When the density results given in Figure 4 are examined, the density of the composites is seen to increase in parallel with the increase in synthesizing time. While the lowest density values were obtained for the samples synthesized for $1 \mathrm{~h}$, the highest density values were obtained for the samples synthesized for 16h. During long-term synthesizing at high temperature, this result indicates that the amount of pores in the structure decreases. With another expression, the density of the composites increases depending on the increase in synthesizing time with the decrease in the amount of pores within the alloy. When the hardness results are examined given in Figure 4b, the hardness values of the AMCs synthesized at different times are seen to be ranged from $44 \mathrm{HV}$ to $50 \mathrm{HV}$. The hardness values of the AMCs synthesized for $1 \mathrm{~h}, 4 \mathrm{~h}$ and $8 \mathrm{~h}$ increase depending on the synthesizing time and the highest hardness value is obtained for the composites $(50 \mathrm{HV})$ synthesized for $8 \mathrm{~h}$. The hardness of AMC synthesized for $16 \mathrm{~h}$ is seen to be decreased. The reason for this is considered to be the grain growth occurred in the structure with increasing synthesizing time of AMCs. Although grain growth with the addition of $6 \%$ Ti to the alloy is partially prevented, grain growth occurs during long-term synthesizing processes at high temperatures. For this reason, a slight reduction in the hardness of composites is seen. In in-situ composite materials produced by adding titanium to the aluminum alloys, two opposite mechanisms confront each other occur. While the first mechanism increases the hardness of in-situ precipitates in the structure with the synthesizing, the second mechanisms cause the increase in the growth of the primer $\alpha$-Al particles. In Figure 5, the relationship between the sliding distances obtained from the wear tests of in-situ AMCs and weight loss is given.

The relationship in Figure 5 shows the increase in the weight loss with increasing sliding distance similar to the other metallic materials ${ }^{41}$. In A356 alloy containing 6\% of $\mathrm{Ti}$, it is seen that there is an increase in the hardness of 
AMCs due to in-situ $\mathrm{TiAl}_{3}$ and AlTiSi intermetallics formed in the structure. The hardness of the AMCs increased for the samples synthesized for $1 \mathrm{~h}, 4 \mathrm{~h}$ and $8 \mathrm{~h}$. As it is known, the weight loss of a material in a wear test decreases with an increase in the hardness of the material ${ }^{8,9}$. Vencl et al. ${ }^{42}$ pointed out that the rate of reinforcement should be increased to reduce plastic deformation and to increase hardness of the material. When the results of weight losses are examined in Figure 5, this situation can be clearly seen. However, the $16 \mathrm{~h}$ synthesized sample encounters higher weight loss. The reason of this is thought to be morphological changes occurred in the material due to the particle growth that is probable to occur in the structure at high temperature $\left(550^{\circ} \mathrm{C}\right)$ because of long synthesizing time and in-situ $\mathrm{TiAl}_{3}$ and AlTiSi intermetallic phase distribution. The distribution of hard precipitates and
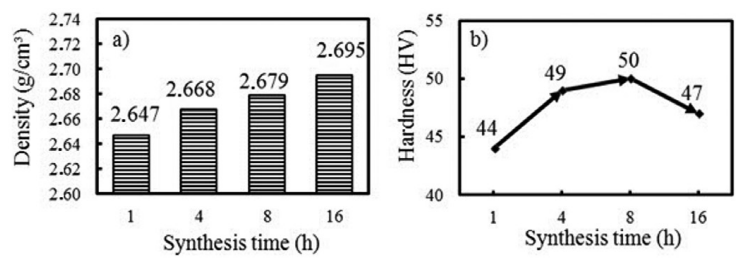

Figure 4. Density (a) and hardness change (b) of A356+6\% $\mathrm{Ti}$ AMCs depending on different synthesizing durations.

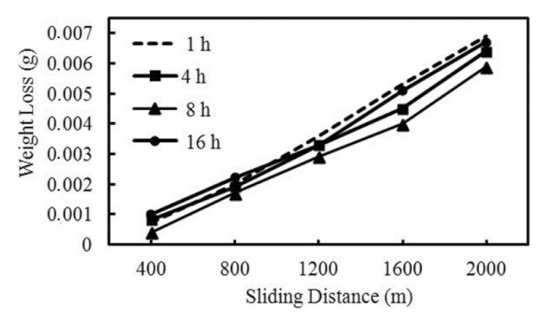

Figure 5. Weight losses in different synthesizing time and sliding distances $\mathrm{A} 356+6 \%$ Ti AMCs.

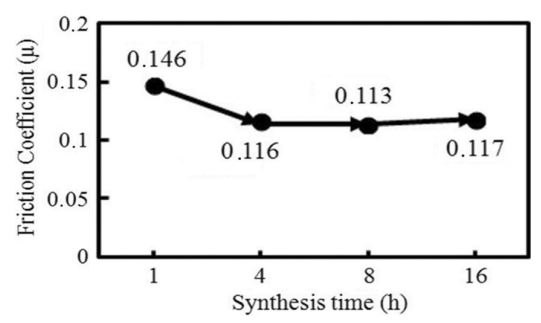

Figure 6. In different synthesizing time and friction coefficient of the A356+6\% Ti AMCs. their sizes affect the hardness and tribological properties of in-situ AMCs. But the synthesizing time did not have a big influence on wear of the samples. It is clearly seen from Figure 4a that hardness results and weight loss results support each other. Wear rate results are given in Table 2 depending on the sliding distances and synthesizing times.

When the wear rate results given in Table 2 are examined, it is seen that the weight losses given in Figure 4 and the wear rates are in good agreement with each other. After $2000 \mathrm{~m}$ sliding distance, the lowest wear rate was obtained for $8 \mathrm{~h}$ synthesized samples while the highest is seen for $16 \mathrm{~h}$ synthesized samples. Saheb et al. ${ }^{43}$ examined the influence of Ti addition to eutectic Al-Si alloy on the wear properties of the alloy. Approximately $40 \mathrm{mg}$ weight loss was recorded for the cast alloy after $2000 \mathrm{~m}$ sliding distance under $19.62 \mathrm{~N}$ load. Therefore, when the results of weight loss obtained in the present study and that obtained by Saheb et al. are compared, the weight loss difference obtained after the wear tests is clearly seen. In this present study, the highest weight loss is approximately $7 \mathrm{mg}$ for $16 \mathrm{~h}$ synthesized sample. When the difference between the weight losses is taken into consideration, the superior wear performance of in-situ AMCs produced with the addition of Ti is seen. In Figure 6, friction coefficient of the A356+6\% Ti AMCs depending on synthesizing time is shown.

Figure 6 shows that increasing synthesizing time up $8 \mathrm{~h}$ decreases the friction coefficient of AMCs synthesized for $1 \mathrm{~h}$, $4 \mathrm{~h}$ and $8 \mathrm{~h}$. In the weight loss of the sample synthesized for $16 \mathrm{~h}$, it is understood that there is a slight increase. The obtained friction coefficient values ranges from 0.146 to 0.113 . When the hardness results given in Figure 4 and the weight loss results given in Figure 5 are compared, it is seen that the weight loss and friction coefficient decrease while the hardness increase. Friction coefficient is an indicator of shear force occurring on the surface of sample/disc contact surface. Shear force occurred with friction depends on the hardness of the material. In Figure 7a-d, the worn surface SEM images of AMCs synthesized for different times are given.

From the SEM image (synthesized for $1 \mathrm{~h}$ ) given in Figure $7 \mathrm{a}$, it is understood that the particles broken off the surface during wear test are adhered to the surface again. Besides that local material losses occurred on the surface can be seen. In Figure 7c, d, the formation of micro cracks is observed on the surface under the influence of deformation in addition to the material losses. Especially, these influences are seen less for the samples synthesized for $8 \mathrm{~h}$. Besides, depending on the increase in the hardness of in-situ AMCs, plastic deformation occurred on the surface decreases. Plastic flow on the samples surfaces generally takes place in the initial stages of wear tests and increases with increasing sliding distance. Vencl et al. ${ }^{44}$ reported the

Table 2. Wear rates in different synthesizing time and sliding distances A356+6\% Ti AMCs.

\begin{tabular}{cccccc}
\hline \multirow{2}{*}{$\begin{array}{c}\text { Synthesizing Time } \\
\text { (h) }\end{array}$} & $\mathbf{4 0 0} \mathbf{~}$ & $\mathbf{8 0 0} \mathbf{~}$ & $\mathbf{1 2 0 0} \mathbf{~}$ & $\mathbf{1 6 0 0} \mathbf{~ m}$ & $\mathbf{2 0 0 0} \mathbf{~ m}$ \\
\cline { 2 - 6 } & 2.203 & 3.148 & 3.777 & 4.171 & 4.344 \\
1 & 2.498 & 2.967 & 3.435 & 3.513 & 3.998 \\
4 & 1.244 & 2.644 & 3.00 & 3.110 & 3.670 \\
8 & 3.115 & 3.426 & 3.426 & 3.971 & 4.174 \\
\hline 16 & & & & & \\
\hline
\end{tabular}



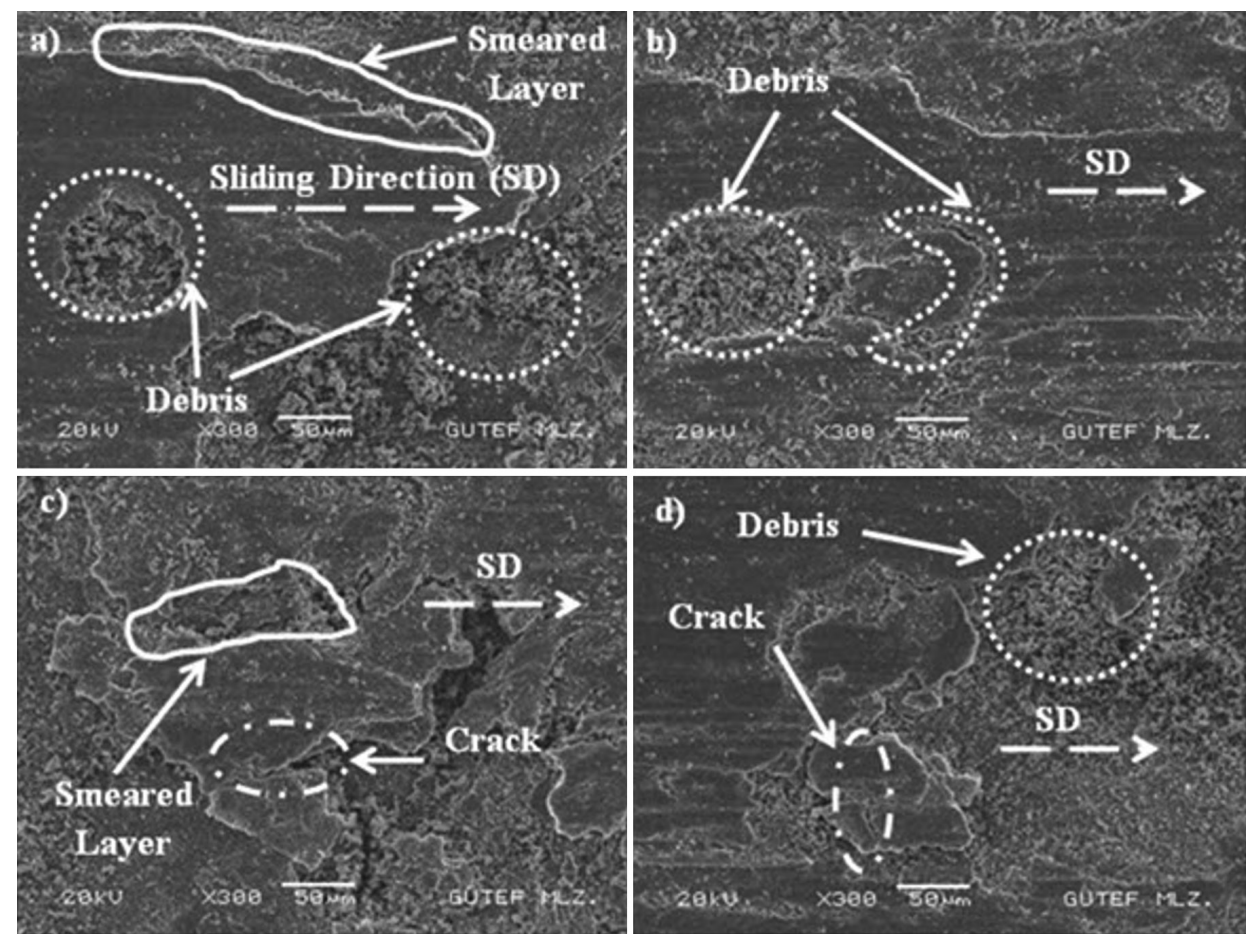

Figure 7. In $550{ }^{\circ} \mathrm{C}$ temperature, abraded surface SEM images of A356+6\% Ti AMCs synthesized for 1 (a), 4 (b), 8 (c) and 16 (d).

occurrence of plastic flow in A356 alloy matrix samples depending on the applied load. Despite this, during wear tests, it was identified that micro cracks occurred with the effect of increasing temperature and deformation on sample/disc contact surface. When the worn surfaces are generally examined, adhesive and abrasive mechanisms are observed to be dominant damage type. These obtained results are supported with a study conducted previously by $\mathrm{Wu} \& \mathrm{Li}^{45}$. Depending on the increase in synthesizing time, the hard $\mathrm{TiAl}_{3}$ phase formed in the structure reduces the weight loss in intermetallic phase. Besides, Prasad et al. ${ }^{46}$ stated that Al-Si alloys containing Ti have the similar effect on wear behavior with primary silicon particles.

\section{Conclusion}

In this study, the effect of $\mathrm{TiAl}_{3}$ and AlTiSi intermetallic phases on dry sliding wear behavior of A $356+6 \%$ Ti AMCs synthesized at $550^{\circ} \mathrm{C}$ for $1,4,8$ and 16 hours was investigated and the below results were obtained:

- Ti was added to A356 alloy through mechanical alloying method and composite materials with

\section{References}

1. Baradeswaran A, Vettivel SC, Perumal AE, Selvakumar N and Issac RF. Experimental investigation on mechanical behaviour, modelling and optimization of wear parameters of B4C and graphite reinforced aluminium hybrid composites. Materials \& Design. 2014; 63:620-632. http://dx.doi.org/10.1016/j. matdes.2014.06.054.
Al-matrix (AMCs) (1, 4, 8 and 16h) were successfully synthesized.

- It was determined that $\mathrm{TiAl}_{3}$ and $\mathrm{AlTiSi}$ intermetallic phases in A356+6\% Ti AMCs were formed depending on the synthesizing time.

- $\mathrm{TiAl}_{3}$ and AlTiSi intermetallic compounds were observed to be formed especially on the grain boundaries (with the effect of diffusion). In addition, the gaps between the grains were found to decrease with increasing synthesizing time. The decreasing gap therefore increased the contact surface and promoted the formation intermetallic phases.

- With the increase in synthesizing time of A356+6\% Ti AMCs, the density increased. The density of A356+6\% Ti AMC synthesized for $1 \mathrm{~h}$ was measured to be $2.647 \mathrm{~g} / \mathrm{cm}^{3}$ while the density of $16 \mathrm{~h}$ synthesized A $356+6 \%$ Ti AMCs was measured to be $2.695 \mathrm{~g} / \mathrm{cm}^{3}$.

- Adhesive and abrasive wear mechanism was seen to be dominant as the result of plastic deformation occurred on the wear surfaces of A356+6\% Ti AMCs.

2. Khoshhal R, Soltanieh M and Boutorabi MA. Formation mechanism and synthesis of $\mathrm{Fe}-\mathrm{TiC} / \mathrm{Al} 2 \mathrm{O} 3$ composite by ilmenite, aluminum and graphite. International Journal of Refractory Metals \& Hard Materials. 2014; 45:53-57. http:// dx.doi.org/10.1016/j.ijrmhm.2014.03.002.

3. Walczak M, Pieniak D and Zwierzchowski M. The tribological characteristics of $\mathrm{SiC}$ particle reinforced aluminium composites. 
Archives of Civil and Mechanical Engineering. 2015; 15(1):116123. http://dx.doi.org/10.1016/j.acme.2014.05.003.

4. Sohi MH, Hojjatzadeh SMH, Moosavifar SS and Heshmati-Manesh S. Liquid phase surface melting of AA8011 alumium alloy by addition of A1/A12O3 nano-composite powders synthesized by high-energy milling. Applied Surface Science. 2014; 313:76-84. http://dx.doi.org/10.1016/j.apsusc.2014.05.143.

5. Peng T and Chang I. Mechanical alloying of multi-walled carbon nanotubes reinforced aluminum composite powder. Powder Technology. 2014; 266:7-15. http://dx.doi.org/10.1016/j. powtec.2014.05.068.

6. Thangarasu A, Murugan N, Dinaharan I and Vijay SJ. Synthesis and characterization of titanium carbide particulate reinforced AA6082 aluminium alloy composites via friction stir processing. Archives of Civil and Mechanical Engineering. 2015; 15(2):324334. http://dx.doi.org/10.1016/j.acme.2014.05.010.

7. Shin JH, Choi HJ and Bae DH. The structure and properties of 2024 aluminum composites with $\mathrm{TiO} 2$ nanoparticles. Materials Science and Engineering A. 2014; 607:605-610. http://dx.doi. org/10.1016/j.msea.2014.04.038.

8. Özyürek D and Tekeli S. An Investigation on wear resistance of SiCp-reinforced aluminium composites produced by mechanical alloying. Science and Engineering of Composite Materials. 2010; 17(1):31-38. http://dx.doi.org/10.1515/SECM.2010.17.1.31.

9. Özyürek D, Tekeli S, Güral A, Meyveci A and Gürü M. Effect of $\mathrm{Al} 2 \mathrm{O} 3$ amount on microstructure and wear properties of $\mathrm{Al}-\mathrm{Al} 2 \mathrm{O} 3$ metal matrix composites prepared using mechanical alloying method. Powder Metallurgy and Metal Ceramics. 2010; 49(5-6):289-294. http://dx.doi.org/10.1007/s11106-010-9235-3.

10. Özyürek D and Çiftçi I. An investigation into wear behaviour of TiB2 particle reinforced aluminum composites produced by mechanical alloying. Science and Engineering of Composite Materials. 2011; 18(1-2):5-12. http://dx.doi.org/10.1515/ secm.2011.003.

11. Aztekin H, Özyürek D and Çetinkaya K. Production of hypo-eutectic Al-Si alloy based metal matrix composite with thixomoulding processing. High Temperature Material Processes. 2010; 29(3):169-178.

12. Ahmed S, Haseeb ASMA and Kurny ASW. Study of the wear behaviour of Al-4.5 Cu-3.4\% Fe in-situ composite: Effect of thermal and mechanical processing. Journal of Materials Processing Technology. 2007; 182(1-3):327-332. http://dx.doi. org/10.1016/j.jmatprotec.2006.08.009.

13. Qiu C, Liu Y, Huang L, Liu B, Zhang W, He Y, et al. Tuning mechanical properties for $\beta(\mathrm{B} 2)$-containing TiAl intermetallics. Transactions of Nonferrous Metals Society of China. 2012; 22(11):2593-2603. http://dx.doi.org/10.1016/S1003-6326(11)61505-7.

14. Niu L, Zhang J and Yang X. In-situ synthesis of Al3 Ti particles reinforced Al-based coating. Transactions of Nonferrous Metals Society of China. 2012; 22(6):1387-1392. http://dx.doi. org/10.1016/S1003-6326(11)61330-7.

15. Chianeh VA, Hosseini HRM and Nofar M. Micro structural features and mechanical properties of Al-Al3Ti composite fabricated by in-situ powder metallurgy route. Journal of Alloys and Compounds. 2009; 473(1-2):127-132. http://dx.doi. org/10.1016/j.jallcom.2008.05.068.

16. Hsu CJ, Chang CY, Kao PW, Ho NJ and Chang CP. 3Ti nanocomposites produced in situ by friction stir processing. Acta Materialia. 2006; 54(19):5241-5249. http://dx.doi.org/10.1016/j. actamat.2006.06.054.

17. Wu W, Abliz D, Jiang B, Ziegmann G and Meiners D. A novel process for cost effective manufacturing of fiber metal laminate with textile reinforced pCBT composites and aluminum alloy.
Composite Structures. 2014; 108:172-180. http://dx.doi. org/10.1016/j.compstruct.2013.09.016.

18. Maqbool A, Hussain MA, Khalid FA, Bakhsh N, Hussain A and Kim MH. Mechanical characterization of copper coated carbon nanotubes reinforced aluminum composites. Materials Characterization. 2013; 86:39-48. http://dx.doi.org/10.1016/j. matchar.2013.09.006.

19. Erarslan Y. Wear performance of in-situ aluminum matrix composite after micro-arc oxidation. Transactions of Nonferrous Metals Society of China. 2013; 23(2):347-352. http://dx.doi. org/10.1016/S1003-6326(13)62468-1.

20. Kumar S, Panwar RS and Pandey OP. Effect of dual reinforced ceramic particles on high temperature tribological properties of aluminum composites. Ceramics International. 2013;39(6):63336342. http://dx.doi.org/10.1016/j.ceramint.2013.01.059.

21. Ramnath BV, Elanchezhian C, Jaivignesh M, Rajesh S, Parsvajinan $\mathrm{C}$ and Ghias ASA. Evaluation of mechanical properties of aluminium alloy-alumina-boron carbide metal matrix composites. Materials \& Design. 2014; 58:332-338. http://dx.doi.org/10.1016/j.matdes.2014.01.068.

22. Bradbury CR, Gomon JK, Kollo L, Kwon H and Leparoux M. Hardness of multi wall carbon nanotubes reinforced aluminium matrix composites. Journal of Alloys and Compounds. 2014; 585:362-367. http://dx.doi.org/10.1016/j.jallcom.2013.09.142.

23. Gao T, Li P, Li Y and Liu X. Influence of Si and Ti contents on the microstructure, microhardness and performance of TiAlSi intermetallics in Al-Si-Ti alloys. Journal of Alloys and Compounds. 2011; 509(31):8013-8017. http://dx.doi. org/10.1016/j.jallcom.2011.05.032.

24. Ghomashchi R. The evolution of AlTiSi intermetallic phases in Ti-added A356 Al-Si alloy. Journal of Alloys and Compounds. 2012; 537:255-260. http://dx.doi.org/10.1016/j.jallcom.2012.04.087.

25. Chandrashekharaiah TM and Kori SA. Effect of grain refinement and modification on the dry sliding wear behaviour of eutectic Al-Si alloys. Tribology International. 2009; 42(1):59-65. http:// dx.doi.org/10.1016/j.triboint.2008.05.012.

26. Zhao H, Wang J, Song Y and Guan S. Microstructure and synthesis mechanism of Al-Ti-C-Sr master alloy. Transactions of Nonferrous Metals Society of China. 2010; 20(5):751-756. http://dx.doi.org/10.1016/S1003-6326(09)60209-0.

27. Zhao H, Bai H, Wang J and Guan S. Preparation of Al-Ti-CSr master alloy and their refining efficiency on A356 alloy. Materials Characterization. 2009; 60(5):377-383. http://dx.doi. org/10.1016/j.matchar.2008.10.012.

28. Jiang C. First-principles study of site occupancy of dilute 3d, $4 \mathrm{~d}$ and $5 \mathrm{~d}$ transition metal solutes in L10 TiAl. Acta Materialia. 2008; 56(20):6224-6231. http://dx.doi.org/10.1016/j. actamat.2008.08.047.

29. Vencl A, Rac A and Bobic I. Tribological behavior of Al-based MMCs and their application in automotive industry. Tribology in Industry. 2004; 26(3-4):31-38.

30. Zhao N, Nash P and Yang X. The effect of mechanical alloying on $\mathrm{SiC}$ distribution and the properties of 6061 aluminum composite. Journal of Materials Processing Technology. 2005; 170(3):586592. http://dx.doi.org/10.1016/j.jmatprotec.2005.06.037.

31. Arik $\mathrm{H}$. Effect of mechanical alloying process on mechanical properties of $\alpha$-Si3N4 reinforced aluminum-based composite materials. Materials \& Design. 2008; 29(9):1856-1861. http:// dx.doi.org/10.1016/j.matdes.2008.03.010.

32. Hassani A, Bagherpour E and Qods F. Influence of pores on workability of porous $\mathrm{Al} / \mathrm{SiC}$ composites fabricated through powder metallurgy + mechanical alloying. Journal of Alloys and Compounds. 2014; 591:132-142. http://dx.doi.org/10.1016/j. jallcom.2013.12.205. 
33. Lara RD, Castaneda EG, Guel IE, Guel GH, Ruiz GH, Sanches EG, et al. Structural characterization of aluminium alloy 7075-graphite composites fabricated by mechanical alloying and hot extrusion. Materials and Design . 2014; 53:1104-1111.

34. Mobasherpour I, Tofigh AA and Ebrahimi M. Effect of nano-size $\mathrm{A} 12 \mathrm{O} 3$ reinforcement on the mechanical behavior of synthesis 7075 aluminum alloy composites by mechanical alloying. Materials Chemistry and Physics. 2013; 138(2-3):535-541. http://dx.doi.org/10.1016/j.matchemphys.2012.12.015.

35. Bustamante RP, Bustamante FP, Guel IE, Rodriguez CRS, Aquino JAM, Ramirez JMH, et al. Characterization of A12024CNTs composites produced by mechanical alloying. Powder Technology. 2011;212(3):390-396. http://dx.doi.org/10.1016/j. powtec.2011.06.007.

36. Nie C, Gu J, Liu J and Zhang D. Investigation on microstructure and interface character of B4C particles reinforced $2024 \mathrm{Al}$ matrix composites fabricated by mechanical alloying. Journal of Alloys and Compounds. 2008; 454(1-2):118-122. http:// dx.doi.org/10.1016/j.jallcom.2006.12.024.

37. Gajewska M, Dutkiewicz J and Morgiel J. Effect of reinforcement particle size on microstructure and mechanical properties of $\mathrm{AlZnMgCu} / \mathrm{AlN}$ nano-composites produced using mechanical alloying. Journal of Alloys and Compounds. 2014; 586:S423-S427. http://dx.doi.org/10.1016/j.jallcom.2012.10.055.

38. Luo X, Yang G and Li C. Preparation of $\mathrm{cBNp} / \mathrm{NiCrAl}$ nanostructured composite powders by a step-fashion mechanical alloying process. Powder Technology. 2012; 217:591-598. http://dx.doi.org/10.1016/j.powtec.2011.11.029.

39. Wang X, Jha A and Brydson R. In situ fabrication of Al3Ti particle reinforced aluminium alloy metal-matrix composites.
Materials Science and Engineering A. 2004; 364(1-2):339-345. http://dx.doi.org/10.1016/j.msea.2003.08.049.

40. Zeren $\mathrm{M}$ and Karakulak E. Influence of Ti addition on the microstructure and hardness properties of near-eutectic $\mathrm{Al}-\mathrm{Si}$ alloys. Journal of Alloys and Compounds. 2008; 450(1-2):255259. http://dx.doi.org/10.1016/j.jallcom.2006.10.131.

41. Özyürek D, Tekeli S, Tuncay T and Yilmaz R. The effect of synthesis time on the wear behavior of Al-8\%Ti alloy produced by mechanical alloying. Powder Metallurgy and Metal Ceramics. 2012; 51(7-8):491-495.

42. Vencl A, Rac A, Bobic I and Miskovic Z. Tribological properties of Al-Si alloy reinforced with $\mathrm{Al} 2 \mathrm{O} 3$ particles. Tribology in Industry. 2006; 28(1-2):27-31.

43. Saheb N, Laoui T, Daud AR, Harun M, Radiman S and Yahaya $\mathrm{R}$. Influence of Ti addition on wear properties of Al-Si eutectic alloys. Wear. 2001; 249(8):656-662. http://dx.doi.org/10.1016/ S0043-1648(01)00687-1.

44. Vencl A, Bobic I, Jovanovic MT, Babic M and Mitrovic S. Microstructural and Tribological properties of A356 Al-Si alloy reinforced with $\mathrm{A} 12 \mathrm{O} 3$ particles. Tribology Letters. 2008; 32(3):159-170. http://dx.doi.org/10.1007/s11249-008-9374-6.

45. Wu JM and $\mathrm{Li} \mathrm{ZZ}$. Contributions of the particulate reinforcement to dry sliding wear resistance of rapidly solidified Al-Ti alloys. Wear. 2000; 244(1-2):147-153. http://dx.doi.org/10.1016/ S0043-1648(00)00452-X.

46. Prasad BK, Vankateswarlu K, Modi OP, Jha AK, Das S, Dasgupta $R$, et al. The effects of primary silicon particles on the sliding behaviour of aluminum-silicon alloys. Journal of Materials Science Letters. 1998; 17(16):1381-1383. http:// dx.doi.org/10.1023/A:1026420211809. 